\title{
Evsel katı atık oluşum miktarlarının küresel ve yerel mekânsal otokorelasyon yöntemleri ile incelenmesi
}

\section{Investigation of generation of municipal solid waste with global and local spatial autocorrelations}

\author{
Gülden Gök ${ }^{1, *(D)}$, Orhan Atakan Gürbüz ${ }^{2}$ (D) \\ ${ }^{I}$ Aksaray Üniversitesi, Çevre Mühendisliği Bölümü, 68100, Aksaray Türkiye \\ ${ }^{2}$ Niğde Ömer Halisdemir Üniversitesi, Çevre Mühendisliği Bölümü, 51240, Niğde, Türkiye
}

\begin{abstract}
Özet
Katı atık oluşumlarının mekânsal olarak incelenmesi evsel katı atık sorunun bölgesel olarak nasıl davrandığını belirtmek açısından oldukça önemlidir. $\mathrm{Bu}$ çalışmada, ortalama günlük kişi başı katı atık miktarları(kg) 2014,2016 ve 2018 yılları için küresel ve yerel mekansal otokorelasyon yöntemleri ile incelenmiştir. Küresel otokorelasyon yöntem sonuçlarına göre katı atık oluşum oranları, istatistiksel olarak anlamlı pozitif otokorelasyon göstermiştir. Moran'nın I indeksi en yüksek 2014 yılı için 0,2980 olarak hesaplanmıştır. Yerel mekansal otokorelasyon yöntemlerinden, yerel Moran'nın I indeksi (LISA) kullanılmıştır. LISA sonuçlarına göre katı atık oluşum oranı düşük seviye olarak Güneydoğu Anadolu Bölgesi ve Doğu Akdeniz bölgelerinde kümelendiği görülmüştür. Yüksek seviyede kümelenme ise Kuzey Batı Trakya ve Ege Bölgelerinde görülmüştür.
\end{abstract}

Anahtar kelimeler: Mekansal otokorelasyon, Moran'nın I indeksi, LISA, Geary'nin C oranı

\section{Giriş}

Kullanım ömrü tükenmiş ve kullanıcısı tarafından atıl olarak değerlendirilen materyal veya objelere atık denilmektedir [1]. Katı atıkların büyük bir kısmı ise insanların günlük aktiviteleri sonucu oluşan ve içerik bakımından çok çeşitli olan, evsel katı atıklardır [1]. Avrupa Birliğinde oluşan toplam atıkların sadece yaklaşık \%9'unu evsel kaynaklı oluşan atıkların oluşturmasına rağmen gelecek 5 yılda evsel katı atık miktarının iki katı artacağ tahmin edilmektedir [2]. Değişen tüketim alışkanlıkları ve yaşam standartları sonucu yıllık yaklaşık olarak 11 milyar ton katı atık oluşmaktadır ve oluşan bu katı atıkların organik kısmı atmosfere salınan sera gazlarının da\%5'ini oluşturmaktadır [3]. Çevresel etkilerini azaltmak, ayrıştırmak ve ekonomik geri dönüşler sağlamak için katı atıklar Türkiye'nin birçok ilinde kontrollü düzenli depolama alanlarında kontrol edilmektedirler [4].

Mekânsal otokorelasyon birbirine yakın konumlanan iki noktanın taşıdığı değerlerinde birbirine yakın olmasını istatiksel olarak açıklayan bir kavramdır. Mekânsal otokorelasyon tekniği ile yapılan birçok farklı alanlarda çalışma vardır ve bu çalıșmalar çevre [5-9], kimya[10],
Abstract

The spatial analysis of the municipal solid waste is significant to clearfy how this issue behaves regionally. The munisipal solid waste $(\mathrm{kg})$ per capita per day was tested both global and local spatial autocorrelation methods. According to the global autocorrelation analysis results, solid waste generation rates showed statistically significant positive autocorrelation. The highest of the calculated Moran's I indexes was found for 2014. Among the local spatial autocorrelation methods, the local Moran's I index (LISA) was used. According to the LISA results, it was observed that the solid waste generation rate was clustered with low leveled values in the Southeastern Anatolia Region and the Eastern Mediterranean regions. The high leveled values were showed a clustered pattern in North Western Thrace and Aegean Regions.

Keywords: Spatial autocorrelation, Moran's I index, LISA, Geary's C ratio

arkeoloji [11], coğrafya [12], turizm[13], jeoloji [14] ve sosyoekonomi [15] gibi birçok alanda bulunmaktadır. Çevre alanında daha çok çevre yönetimi $[5,9]$, ve noktasal kaynaklı kirliliğin mekansal incelenmesine [6, 8] yönelik çalışmalar gerçekleşmiştir.

Mekânsal otokorelasyon analizleri iki ayrı şekilde değerlendirilebilir. Mekânsal otokorelasyon analizlerinin örneklemi bir bütün olarak ele alıp otokorelasyon istatistiğini veren analizlere küresel mekansal otokorelasyon analizleri denir ve en yaygın kullanılan analiz türleri Moran'nın I indeksi ile Geary'nin C istatistiğidir [16]. İkinci çeşit otokorelasyon analiz yöntemleri ise her bir veri unsurunun otokorelasyonlarının hesaplandığı Yerel Moran'nın I indeksi (Local Indicators of Spatial Association (LISA)) ve Getis Ord $\mathrm{Gi}$ istatistiğidir [17, 18]. Bu yerel analizler veri grubunda kümeleşme veya sapan değerlerin mekânsal olarak tespiti için kullanılır [8].

$\mathrm{Bu}$ çalışmanın amacı coğrafi bilgi sistemleri ile çevresel verilerin bir arada kullanılarak katı atıkların oluşum oranlarının illerin mekânsal konumlarına göre dağılımlarının incelenmesidir. Çalışma üç aşamadan oluşmaktadır. İlk aşamada veri toplama ve sayısallaştırma işlemleri temel

* Sorumlu yazar / Corresponding author, e-posta / e-mail: gokgulden@ gmail.com (G. Gök)

Geliş / Recieved: 30.01.2021 Kabul / Accepted: 22.03.2021 Yayımlanma / Published: 27.07.2021

doi: 10.28948/ngmuh.871183 
istatistik yöntemler ve bilgisayar yazılımları ile gerçekleştirilmiştir. İkinci aşamada ise verilerin küresel otokorelasyon yöntemleri ile otokorelasyon durumları ve istatiksel anlamlılıkları tartışılmıştır. Son aşamada ise yerel otokorelasyon yöntemi ile her bir ilin katı atık oluşum miktarları diğer illerin konumlarına göre incelenerek verilerin mekânsal olarak anlamlı kümeler oluşturup oluşturmadıkları incelenmiştir.

\section{Materyal ve metot}

Katı atık verilerinin mekânsal analizinin gerçekleştiği bu çalışmada, nüfus ve katı atık verileri Türkiye İstatistik Kurumu resmi internet sayfasından temin edilmiştir. Belediye atık istatistikleri, TÜİK tarafindan belediyeler tarafından toplanan atık miktarları 2001 yılından 2018 yılına kadar (2004 sonrası veriler iki yılda bir olmak kaydıyla) işlenmiştir [19]. İl nüfus verileri ise 2001-2006 tarihleri arasındaki TÜİK nüfus tahminleri ve 2007-2019 yılları arasındaki il nüfus verilerine ise TÜİK adrese dayalı nüfus kayıt sisteminden alınmıştır [20].

Bununla birlikte bu çalışmada mekânsal ve istatistiksel veriler üç farklı bilgisayar yazılımıyla irdelenmiştir. ArcGIS v.10.5 coğrafi bilgi sistemi yazılımı ile. shapefile uzantılı dosyalar ile TÜİK verileri birleştirilerek istatistiksel analizlere hazır hale getirilmiştir.

İstatistiksel analizler ile küresel mekânsal otokorelasyon analizleri $\mathrm{R}$ programlama dilinde ( $\mathrm{R} \quad \mathrm{v}$ 4.0.3.) gerçekleştirilmiştir. Yerel mekânsal otokorelasyon analizleri için ise GeoDa v1.18 mekânsal veri analizi yazılımı ile gerçekleştirilmiştir. Normal dağılım için gerekli olan veri transformasyonları $\mathrm{R}$ programında ve kümelenme aykırı değerlerin haritalanması GeoDa programlarında gerçekleştirilmiştir [8].

\subsection{Türkiye'nin katı atık durumu}

Küresel ve yerel mekânsal oto korelasyon analizleri için oluşturulması gereken mekânsal ağırlık matrisleri, komşuluk veya noktalar arası mesafe ilişkilerine göre farklı şekillerde oluşturulabilir. Komşuluk ağırlıkları, özellikle poligon şeklinde olan mekânsal verilerin birbirleriyle olan sınır ilişkilerine göre hazırlanan ağırlık matris tablolarından oluşmaktadır. Mesafe ağırlıkları ise genellikle noktasal mekânsal veriler için kullanılır. Mesafe ağırlıkları, iki nokta arasındaki mesafelerin, üssel, dairesel ve ters mesafe olarak hesaplanabilir [21]. Bu çalışmada komşuluk ağırlık matrisi satır standardizasyon yöntemi ve birinci derece "queen" sürekliliği yöntemleri tercih edilerek [21] R programlama dili ve GeoDA programında ağırlık matrisleri oluşturulmuştur. Şekil.1.'de TÜİK verilerine göre Türkiye'nin nüfus ve toplanan katı atık miktarlarının yıllara göre değişimleri görülmektedir. Verilere göre en az toplanan katı atık miktarı 2008 yılında 24360856 ton olarak tespit edilmiştir. En fazla toplan katı atık miktarı ise 2018 yılında

32209219 ton olarak tespit edilmiştir. Tablo 1. 'de 2014, 2016 ve 2018 yıllarında kişi başı atık miktarı verilerinin özet istatistikleri verilmiştir

Türkiye'de iller düzeyinde kişi başı atık miktarı verileri TÜİK tarafindan toplam atık miktarının il nüfusuna oranının 365 güne bölünerek bin ile çarpılmalarıyla [kg/kişi-gün] hesaplanmıştır.
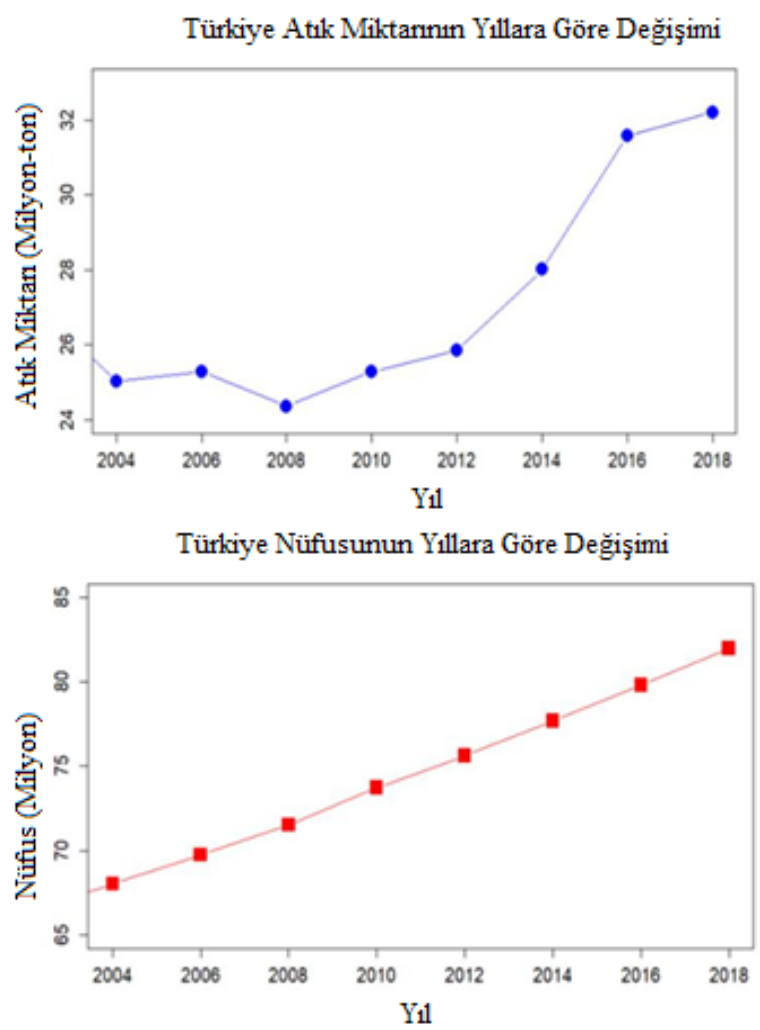

Şekil 1. Nüfus ve toplanan atık miktarlarının yıllara göre değişimi

Tablo 1. Katı Atık Miktarları [kg/gün-kişi]

\begin{tabular}{ccccccc}
\hline Y1llar & Min. & 1. Kartil & Medyan & Ortalama & 3.Kartil & Mak. \\
\hline 2014 & 0.67 & 0.97 & 1.12 & 1.137 & 1.23 & 1.8 \\
2016 & 0.7 & 0.98 & 1.13 & 1.176 & 1.34 & 1.97 \\
2018 & 0.75 & 1 & 1.09 & 1.155 & 1.3 & 2.01 \\
\hline
\end{tabular}

Bu çalışmada, günlük kişi başı üretilen ortalama katı atık miktarından 2014, 2016 ve 2018 yıllarına ait verilerin mekânsal oto korelasyon analizleri kullanılmıştır. 2014 yılında kişi başı ortalama en fazla katı atık üretimi Edirne'dedir (1.81 kg/kişi-gün). 2016 yılında en fazla katı atık üretimi ise Muğla ilinde görülmektedir $(1.97 \mathrm{~kg} / \mathrm{kişi-}$ gün). 2018 yılında ortalama en fazla kişi başı en fazla katı atık miktarı 2,01 kg ile Bartın'dır. Ortalama kişi başı katı atık miktarlarının en düşük olduğu iller 2014, 2016 ve 2018 yılları için sırasıyla Trabzon (0.67 kg/kişi-gün); Kahramanmaraş (0.75 kg/kişi-gün); Kahramanmaraş ve Hakkâri $(0.77$ kg/kişi-gün) olduğu görülmektedir. Mekânsal Otokorelasyon analizleri için sayısal verilerin normal dağılım göstermesi özellikle yerel Moran'nın I indeksi hesaplamalarında çarpıklığa hassasiyet gösteren ortalama ve varyans değerleri için gerekmektedir [8, 22]. 

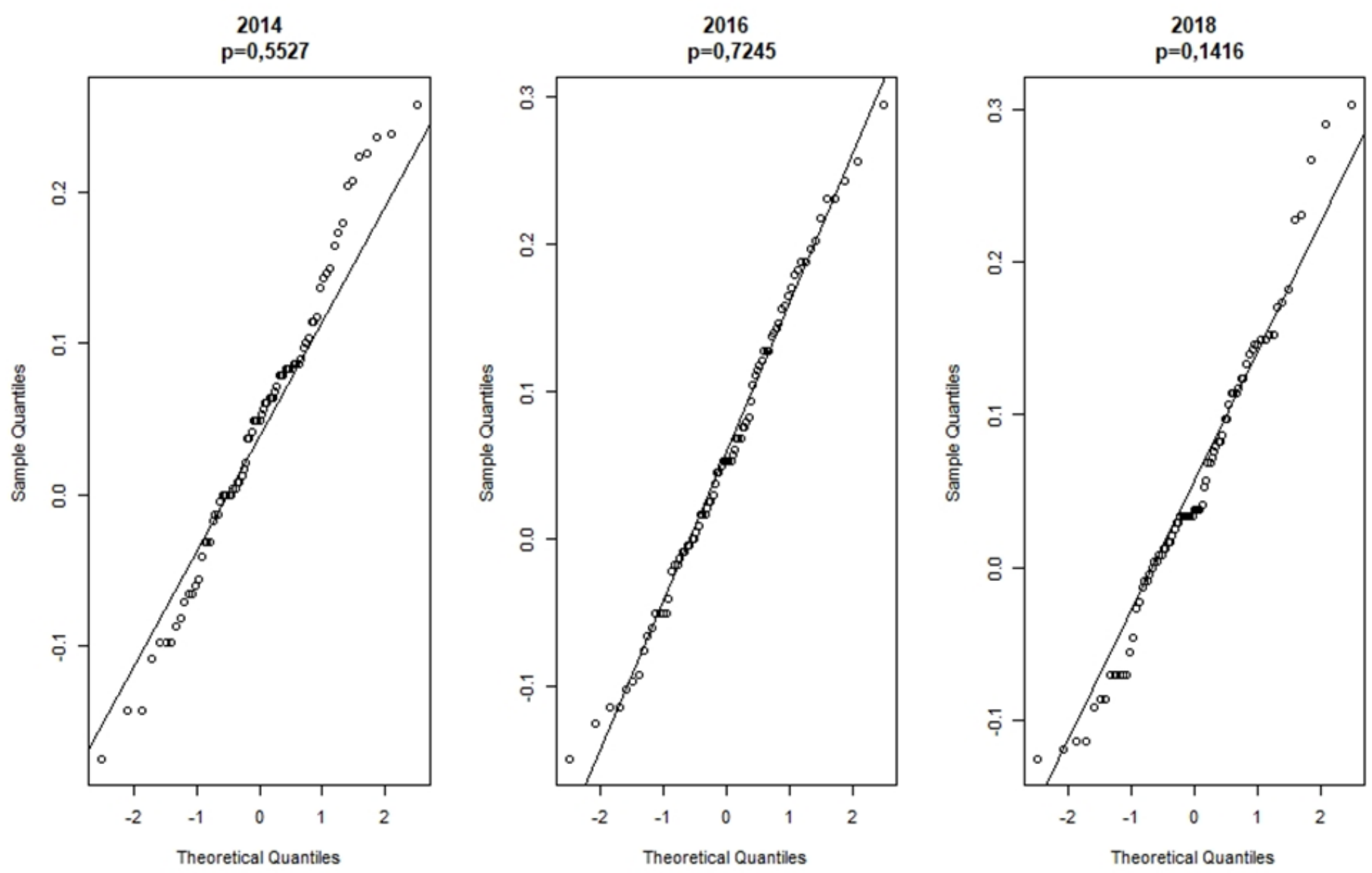

Şekil 2. Kişi başı atık miktarlarının Q-Q grafikleri

Bu nedenle 2014,2016 ve 2018 yıllarına ait ortalama kişi başı atık miktarlarına logaritmik dönüşüm uygulanmıştır. Shapiro-Wilk testi ile normallik testi $[23,24]$ gerçekleştirilmiş ve söz konusu yıllar için p değerlerinin 0,05 'ten büyük olduğu görülmüsştür. Şekil.2'de de görüldüğü üzere verilerin dağıllımlarının normal dağılımdan istatistiksel olarak önemli bir farklı olmadığı görülmektedir.

\subsection{Moran'nin I indeksi ve Geary'nin C istatistiği}

Mekânsal otokorelasyon analizleri değişkenlerin sistematik ve mekânsal olarak dağılıp dağılmadığını gösteren analizlerdir [5, 21]. Mekânsal otokorelasyon pozitif, negatif ve sıfir olarak sinıflandırılabilir [5]. Pozitif mekânsal otokorelasyon değeri veri setinde birbirine yakın olan değerlerin mekânsal olarak da yakın konumlandığı [25], negatif mekânsal otokorelasyon ise birbirlerine yakın değere sahip değişkenlerin mekânsal olarak birbirlerinden uzak konumlandığını [16], sıfir mekânsal otokorelasyon ise değişkenlerin değerlerinin konumlarından bağımsız olduğunu ifade etmektedir [25].

Mekânsal otokorelasyon analizini veri setini bir bütün olarak ele alan türlerinden bu çalışmada Moran'nın I indeksi ile Geary'nin C istatistiğidir kullanılmıştır [16]. Moran'nın I indeksi Denklem (1 2)'deki kullanılarak hesaplanabilir [26]. Moran'nın I indeksi Pearson korelasyon sabiti gibi davranır ve indeks sonuçları -1 ile +1 arasında değişebilir [16].

$$
\begin{gathered}
I=\frac{n}{S_{0}} \frac{\sum_{i=1}^{n} \sum_{j=1}^{n} w_{i j}\left(x_{i}-\bar{x}\right)\left(x_{j}-\bar{x}\right)}{\sum_{i=1}^{n}\left(x_{i}-\bar{x}\right)^{2}} \\
S_{0}=\sum_{i=1}^{n} \sum_{j=1}^{n} w_{i j}
\end{gathered}
$$

Denklemlerde n gözlem sayısını, wij mekânsal ağırlığı, So mekânsal ağırlıklar toplamını, xi i konumuna ait katı atık verisini, $x j \mathrm{j}$ konumuna ait katı atık verisini $\overline{\mathrm{x}}$ katı atık verilerinin aritmetik ortalamasını temsil etmektedir [26].

Geary'nin C istatistiği Moran'nın I indeksinin alternatifidir ve Geary'nin C istatistiği karşılaştırılabilir variogram analizini esas alır [22]. Geary'nin C istatistiği Denklem (3-4) ile hesaplanır [26].

$$
\begin{gathered}
C=\frac{\sum_{l=1}^{n} \sum_{j=1}^{n}\left[w_{i j}\left(x_{i}-x_{j}\right)^{2}\right]}{2 S_{0} S^{2}} \\
S^{2}=\frac{\sum_{i=1}^{n}\left(x_{i}-\bar{x}\right)^{2}}{(n-1)}
\end{gathered}
$$

Denklemlerde n gözlem sayısını, wij mekânsal ağırlığı, So mekânsal ağırlıklar toplamını, xi i konumuna ait katı atık verisini, $\mathrm{xj} \mathrm{j}$ konumuna ait katı atık verisini $\overline{\mathrm{x}}$ katı atık 
verilerinin aritmetik ortalamasını, $\mathrm{S}$ varyansı temsil etmektedir [26]. Geary'nin C istatistiği Moran'nın I indeksinden farklı olarak $\mathrm{C}$ oranın 0 ile 1 arasında olması birbirine yakın olan konumların değerlerinin de birbirlerine yakın olduğunu (pozitif otokorelasyon), C oranın 1'e yaklaşık eşit olduğu durumlarda ise rastgele dağılım( nötr otokorelasyon), C oranın 1 ile 2 değeri arasında olmasında da yakın konumdaki değerlerin farklılık göstermektedir (negatif otokorelasyon) [27].

\subsection{Yerel Moran'nın I indeksi (Local Indicators of Spatial Association (LISA))}

Moran'nın I indeksi ve Geary'nin C istatistiği gibi mekânsal otokorelasyon analizleri veri setinin bütününü ele alıp mekânsal otokorelasyonun yorumlanması için tek bir istatistik vermektedir. Yerel indeksler ise, örneklemin konumlarının ayrı ayrı analizlerine olanak sağlamaktadır. Böylelikle mekânsal dağılımın kümelenme ya da rastgele şekilde olup olmadığı belirlenebilmektedir $[22,26]$.

Mekânsal ilişkiyi gözlemler boyutunda irdeleyen ilk istatistiksel yöntemlerden biri Getis-Ord Gi* istatistiğidir [18]. Yerel mekânsal otokorelasyon analiz tekniklerinden bir diğeri ise LISA'dır [17]. Getis-Ord Gi*'dan farklı olarak LISA mekânsal uçdeğerlerin tespit edilmesini kolaylaştırır ve bu uçdeğerler komşularının değerlerine göre oldukça farklılık gösteren değerlere denir [28]. LISA Denklem (5) ve Denklem (6)'e göre hesaplanmaktadır [29]. Getis Ord Gi* istatistiğinden farklı olarak LISA değerleri küresel Moran I değeri ile ilişkilidir bu nedenle bu çalışmada [17]. LISA değerlerinin aritmetik ortalamaları çalışma alanın küresel Moran I indeksini verir [17].

$$
\begin{gathered}
I_{i}=\frac{x_{i}-\bar{X}}{S_{i}^{2}} \sum_{j=1, j \neq i}^{n} w_{i, j}\left(x_{i}-\bar{X}\right) \\
S_{i}^{2}=\frac{\sum_{j=1, j \neq i}^{n} w_{i, j}}{n-1}-\bar{X}^{2}
\end{gathered}
$$

\section{Bulgular ve tartışma}

Türkiye'nin katı atık oluşum miktarlarının 2014,2016 ve 2018 yıllarına göre mekânsal dağılım sonuçları Tablo 2.'de verilmiştir. Bu tabloya göre, 2014 yılında I indeksi pozitif ve sıfırdan büyük bir değerdedir. Bu nedenle, 2014 yılına ait katı atık oluşum miktarlarının birbirine yakın olan illerde benzer olduğu anlaşılmaktadır. Benzer veri değerlerine sahip illerin birbirlerine yakın konumda oldukları \%99 düzeyinde istatiksel olarak anlamlıdır. 2016 yılında I istatistiği pozitif bu nedenle birbirine komşu olan illerdeki katı atık oluşum oranları da birbirlerine yakın olduğu ve bu yakınlığın \%95 oranında anlamlı olduğu anlaşılmaktadır. 2018 yılında katı atık oluşum oranları da pozitif otokorelasyon göstermektedir. $\mathrm{Bu}$ pozitif otokorelasyon \%95 oranında istatistiksel olarak anlamlıdır.

Geary’nin C istatistiğine göre 2014,2016 ve 2018 yıllarında katı atık oluşum oranlarının mekânsal dağılımları pozitif otokorelasyon göstermektedir. 2014 y1lına ait Geary'nin C değeri \%99 oranında anlamalıdır. 2016 ve 2018 yıllarına ait bu istatistik ise $\% 95$ anlamlı olduğu görülmüştür.
Şekil 3. LISA yerel otokorelasyon analiz sonuçlarının istatistiksel olarak anlamlı olanları göstermektedir İstatiksel anlamlılık derecesi $\mathrm{p}$ değeri sonuçları yine Şekil 3.'de gösterilmiştir.

2014 yılı katı atık oluşum oranlarına göre batıda Tekirdağ, Kırklareli ve Çanakkale'de yüksek katı atık oluşum miktarları ve konumlarının yakınlığından küme oluşturmuşlardır.

Tablo 2. Küresel Mekânsal Otokorelasyon Analiz Sonuçları

\begin{tabular}{ccccc}
\hline & & 2014 & 2016 & 2018 \\
\hline & I değeri & 0.2980 & 0.1644 & 0.1991 \\
$\begin{array}{c}\text { Moran'nın I } \\
\text { indeksi }\end{array}$ & Z değeri & 4.3042 & 2.4531 & 2.9338 \\
& P değeri & 0.00 & 0.007082 & 0.001674 \\
\hline & C değeri & 0.6936 & 0.8042 & 0.7637 \\
$\begin{array}{c}\text { Geary'nin C } \\
\text { istatistiği }\end{array}$ & Z değeri & 3.9751 & 2.5393 & 3.0657 \\
& P değeri & 0.00 & 0.005554 & 0.001086 \\
\hline
\end{tabular}

Güneydoğu Anadolu'da ise Van, Şırnak, Muş, Batman ve Siirt'in düşük değerlerle bir küme oluşturduğu görülmektedir. Kuzeyde Bayburt ve Rize'nin katı atık oluşum oranlarının düşük ve bu oranların birbirleri ile mekânsal ilişkilerinin olduğu görülmektedir. Güneyde ise Sivas, Adana, Kahramanmaraş, Osmaniye, Gaziantep, Adıyaman kümelenme açısından en büyük soğuk bölge kümelenmeyi oluşturmaktadır.

2016 y1lında soğuk bölgelerin daha belirgin bir şekilde yoğun kümelendiği görülmektedir. Adana, Osmaniye, Sivas, Erzincan, Şanlıurfa, Diyarbakır, Batman ve Muş soğuk noktaları oluşturmaktadır. Ayrıca bu kümeden bağımsız olarak Rize katı atık oluşum oranın düşük olduğu ilimizdir. Sıcak noktalar Ege Bölgesinde İzmir, Aydın, Denizli illerinde kümelenmiş, Marmara Bölgesinden Tekirdağ ve Çanakkale olmak üzere kümelenmiştir.

2018 yılında ise Marmara bölgesindeki sicak bölge kümeleşmesinin devam ettiği görülmektedir. Ege Bölgesinde Aydın, Denizli ve Burdur sicak bölge kümesi oluşturmaktadır. 2016 yılında görülen soğuk bölgeden 2018 yılında Sivas'ın ayrıldığı ve Hatay'ın eklendiği görülmektedir. Şekil 3.'de görülen tek başına soğuk veya sıcak bölge özelliği gösteren iller ise istatiksel anlamlılık güven düzeyi düşürüldüğünde potansiyel kümeleşmenin olacağı bölgeleri belirtmektedir.

Sivas'ın 2014 yılında ortalama katı atık oluşum miktarı komşu illerin katı atık değerlerine göre daha fazladır ve bu fark istatiksel olarak anlamlıdır. 2014 yılında diğer bir dışsallık örneği gösteren il Bayburt olduğu görülmektedir. 2016 yılında Rize, Erzincan, Sivas ve Batman illeri komşularına göre daha fazla katı atık üreten iller olmuşlardır. Denizli, Zonguldak ve Kastamonu ise sınır komşularına göre günlük kişi başı ortalama katı atık miktarları daha azdır. Düşük değerlerin en belirgin kümeyi oluşturduğu 2018 yılında ise yüksek sapma verileri Hatay, Erzincan ve Rize illerinde, düşük sapma değerleri ise 2016 yılında olduğu gibi Denizli, Zonguldak ve Kastamonu illerinde görülmüştür. 


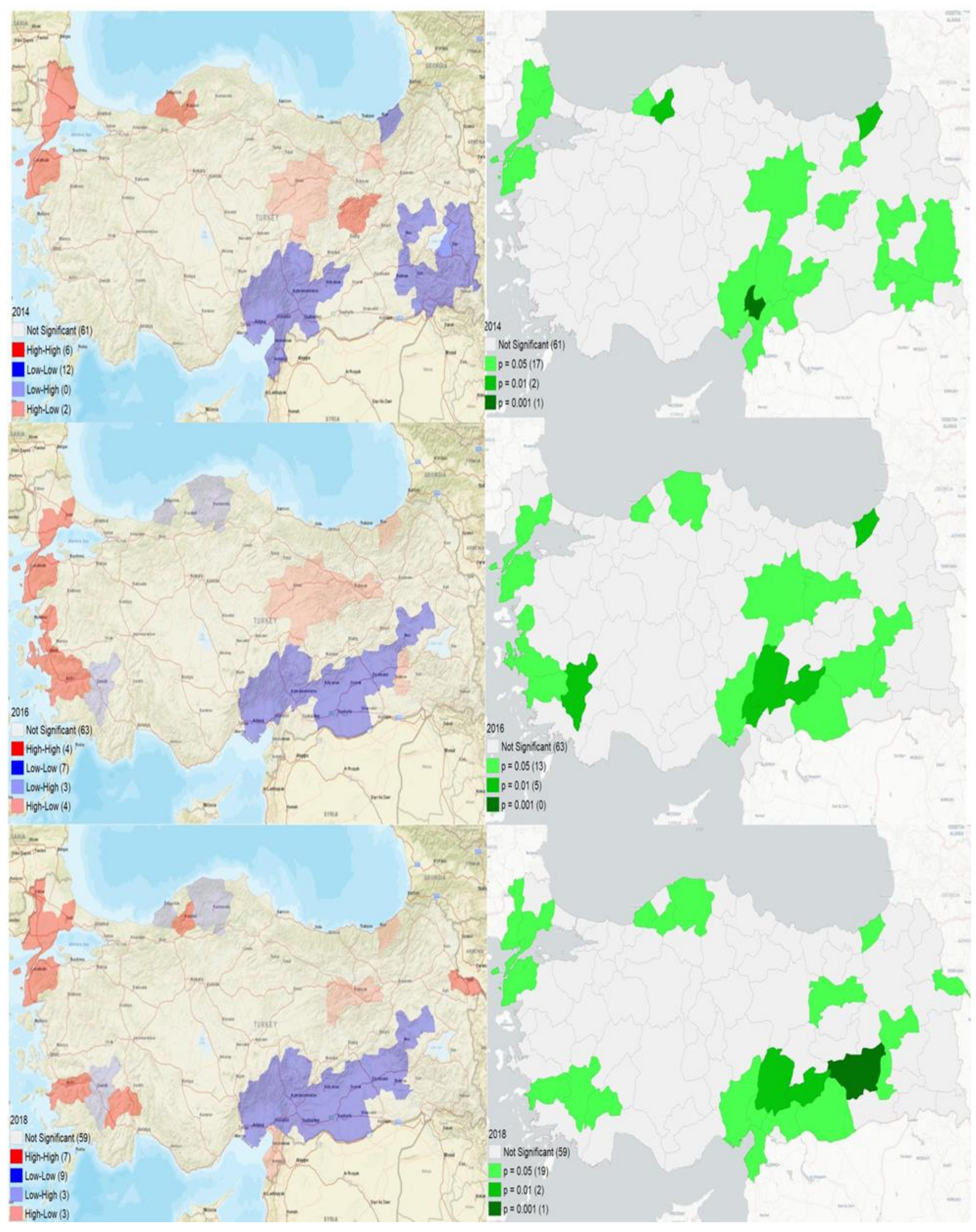

Şekil 3. 2014, 2016 ve 2018 yılları LISA analiz sonuçları, solda sıcak bölge, soğuk bölge analizi; sağda, istatistiksel önem değerleri 


\section{Sonuçlar}

Mekânsal otokorelasyon analizlerinin hem küresel hem de yerel boyutları kişi başı ortalama yıllık katı atık miktarları için anlamalı sonuçlar verdiği görülmüştür. Küresel otokorelasyon analizlerinin sonuçlarına göre Türkiye'de katı atık oluşum oran verileri pozitif otokorelasyon göstermektedir. Ayrıca bu mekânsal bağlantı istatiksel güven düzeyleri arasındadır.

Yerel otokorelasyon analizleri sonucunda özellikle 2016 ve 2018 y1llarında Güneydoğu Anadolu Bölgesi ve Doğu Akdeniz bölgesinde günlük katı atık oluşum miktarlarının düşük olduğu illerin mekânsal olarak anlamlı bir şekilde bir arada bulunduğu görülmektedir. Nüfus verileri incelendiğinde bu kümelen illerin nüfuslarının çok değişken olduğu bilinmektedir.

Yerel otokorelasyon analizleri sonucu mekânsal ağırlıklı ortalamadan fazla olan katı atık değerlerinin Özellikle Ege ve Marmara Bölgesinin bazı illerinde görülmüştür. Ülke ortalamasından fazla değerlerin bir arada kümelenmeleri en belirgin olarak 2016 yılında görülmüştür:

Özellikle yerel boyuttaki mekânsal analiz yöntemleri problemi tespit etme veya değişimi belirleme için oldukça kullanışlı analiz yöntemleridir. Çevre alanında, katı atıkların oluşum miktarları bölgesel olarak değerlendirilmesi aşamasında, ya da bölgesel olarak atık oluşumunu azaltmaya yönelik uygulamaların sonuçlarının değerlendirilmesi için bu çalışmada kullanılan analiz yöntemleri durum değerlendirmesi ve çevre politikalarını yönetme açısından faydalı olacağı düşünülmektedir. Katı atık oluşum oranlarının mekânsal bir düzende değişiklik göstermesi ve istatiksel olarak anlamlı olması diğer çevresel, demografik veya coğrafi parametreleri dahil edilmesi ile daha geniş kapsamlı neden sonuç ilişkileri ortaya koyması açısından önemli olacağı düşünülmektedir.

\section{Çıkar çatışması}

Yazarlar çıkar çatışması olmadığını beyan etmektedir.

\section{Benzerlik oranı (iThenticate): $\% 6$}

\section{Kaynaklar}

[1] C. O. Ugwu, C. G. Ozoegwu, and P. A. Ozor, Solid waste quantification and characterization in university of Nigeria, Nsukka campus, and recommendations for sustainable management. Heliyon, 6 (6), e04255, 2020. https://doi.org/https://doi.org/10.1016/j.heliyon.2020.e 04255

[2] E. Stunzenas and I. Kliopova, Optimizing municipal biodegradable waste management system to increase biogas output and nutrient recovery: a case study in Lithuania. Energy Procedia, 147, 641-648, 2018. https://doi.org/https://doi.org/10.1016/j.egypro.2018.0 7.083

[3] L. R. Luttenberger, Waste management challenges in transition to circular economy - Case of Croatia. Journal of Cleaner Production, 256, 120495, 2020. https://doi.org/https://doi.org/10.1016/j.jclepro.2020.1 20495
[4] G. Gök, Estimation of methane generation and energy potential of Nigde landfill site using first order mathematical modelling approaches. journal of engineering sciences and design, 7 (1), 126-135, 2019.

[5] S. Keser, S. Duzgun, and A. Aksoy, Application of spatial and non-spatial data analysis in determination of the factors that impact municipal solid waste generation rates in Turkey. Waste Management, 32 (3), 359-71, 2012. https://doi.org/10.1016/j.wasman.2011.10.017

[6] Y. Li, Y. Cui, B. Cai, J. Guo, T. Cheng, and F. Zheng, Spatial characteristics of $\mathrm{CO} 2$ emissions and PM2.5 concentrations in China based on gridded data. Applied Energy, 266, 2020.https://doi.org/10.1016/j.apenergy .2020 .114852

[7] F. Fan, H. Lian, X. Liu, and X. Wang, Can environmental regulation promote urban green innovation Efficiency? An empirical study based on Chinese cities. Journal of Cleaner Production, 2020. https://doi.org/10.1016/j.jclepro.2020.125060

[8] C. Zhang, L. Luo, W. Xu, and V. Ledwith, Use of local Moran's I and GIS to identify pollution hotspots of $\mathrm{Pb}$ in urban soils of Galway, Ireland. Sci Total Environ, 398 (1-3), 212-21, 2008. https://doi.org/10.1016/ j.sci totenv.2008.03.011

[9] M. Agovino, M. D'Uva, A. Garofalo, and K. Marchesano, Waste management performance in Italian provinces: Efficiency and spatial effects of local governments and citizen action. Ecological Indicators, 89, 680-695, 2018. https://doi.org/10.1016/ j.ecolind .2018 .02 .045

[10] E. S. Thompson, P. Saveyn, M. Declercq, J. Meert, V. Guida, C.D. Eads, E.S.J. Robles, and M.M. Britton, Characterisation of heterogeneity and spatial autocorrelation in phase separating mixtures using Moran's I. J Colloid Interface Sci, 513, 180-187, 2018. https://doi.org/10.1016/j.jcis.2017.10.115

[11] L. S. Premo, Local spatial autocorrelation statistics quantify multi-scale patterns in distributional data: an example from the Maya Lowlands. Journal of Archaeological Science, 31 (7), 855-866, 2004. https ://doi.org/https://doi.org/10.1016/j.jas.2003.12.002

[12] E. M. Özgür and O. Aydın, Türkiye'de Evlilik Göçünün Mekânsal Veri Analizi Teknikleriyle Değerlendirilmesi (The Evaluation of Marriage Migration Using Spatial Data Analysis Techniques in Turkey). Coğrafi Bilimler Dergisi/Turkish Journal of Geographical Sciences, 9 (1), 29-40, 2011.

[13] D. Yüncü, İ.O. Coşkun, Y. Mert Kantar, S. Günay Aktaş, and H. Sezerel, Turist Çekicilikleri Ve Turist Akişi Arasindaki IliŞkilerin Mekansal BaĞimliliĞa Dayali Olarak Incelenmesi. e-Journal of New World Sciences Academy, 12 (4), 232-247, 2017. https://doi .org/10.12739/nwsa.2017.12.4.3c0168

[14] Ö. TÜRKŞEN, Mekansal istatistiklerin bir uygulaması: Simule edilmiş fay düzlemine ilişkin jeodezik noktaların mekansal analizi. Balıkesir Üniversitesi Fen 
Bilimleri Enstitüsü Dergisi, 1-13, 2019. https://doi.org/ 10.25092/baunfbed.522967

[15] Ç. L. Uslu, Provincial Income Inequality and Spatial Autocorrelation Across Turkish Provinces: 1992-2013. Sosyoekonomi, 25 (34), 197-211, 2017. https://doi.org/ 10.17233/sosyoekonomi.315759

[16] M. A. Kalkhan, Spatial Statistics GeoSpatial Information Modeling and Thematic Mapping 2011, Boca Raton, FL: CRC Press. 178.

[17] L. Anselin, Local Indicators of Spatial AssociationLISA. 27 (2), 93-115, 1995. https://doi.org/https:// doi.org/10.1111/j.1538-4632.1995.tb00338.x

[18] A. Getis and K. Ord, The Analysis of Spatial Association by Use of Distance Statistics. Geographical Analysis, 24, 189-206, 1992. https:// doi.org/10.1111/j.1538-4632.1992.tb00261.x

[19] TÜİK. Çevre İstatistikleri. [cited 2020 22.11.2020]; Available from:https://tuikweb.tuik .gov.tr/PreTablo .do?alt_id=1019.

[20] TÜİK. Nüfus İstatistikleri. [cited 2020 22.11.2020]; Available from: https://tuikweb.tuik.gov.tr/ UstMenu .do?metod=temelist.

[21] K. Suryowati, R. D. Bekti, and A. Faradila, A Comparison of Weights Matrices on Computation of Dengue Spatial Autocorrelation. IOP Conference Series: Materials Science and Engineering, 335, 2018. https://doi.org/10.1088/1757-899x/335/1/012052

[22] R. E. Plant, Spatial Data Analysis in Ecology and Agriculture Using R Vol. Second Edition. 2019, Boca Raton, FL: CRC Press Taylor \& Francis Group. 685.
[23] A. Ghasemi and S. Zahediasl, Normality tests for statistical analysis: a guide for non-statisticians. Int $\mathbf{J}$ Endocrinol Metab, 10 (2), 486-9, 2012. https:// doi .org/10.5812/ijem.3505

[24] G. Tepanosyan, L. Sahakyan, C. Zhang, and A. Saghatelyan, The application of Local Moran's I to identify spatial clusters and hot spots of $\mathrm{Pb}$, Mo and $\mathrm{Ti}$ in urban soils of Yerevan. Applied Geochemistry, 104, 116-123, 2019.https://doi.org/ 10.1016/ j.apgeochem .2019 .03 .022

[25] A. Neşe and M. Aytaç, Türkiye'de işsizliğin mekânsal analizi. Öneri Dergisi, 13 (49), 1-20, 2018.

[26] K. M. Çubukçu, Planlamada ve Coğrafyada Temel İstatistik ve Mekansal İstatistik. Vol. 2. Basım. 2019: Nobel 323.

[27] J. Lee, Wong, W. S., Statistical Analysis with ArcView GIS 2001, New York, NY: John Wiley \& Sons.

[28] S. Hafeez, M. Amin, and B.A. Munir, Spatial mapping of temporal risk to improve prevention measures: A case study of dengue epidemic in Lahore. Spat Spatiotemporal Epidemiol, 21, 77-85, 2017. https:// doi.org/10.1016/j.sste.2017.04.001

[29] M. A. Dereli, Polat, Nizar, Boşanma Verilerinin Coğrafi Bilgi Sistemleri Destekli Mekânsal İstatistiksel Yöntemler ile İrdelenmesi. Harran Üniversitesi Mühendislik Dergisi, 3 (3), 112-118, 2018. 